\title{
LATE WEICHSELIAN POTHOLES NEAR WOLVERHAMPTON, ENGLAND
}

\author{
By Alan V. Morgan \\ (Department of Geology, University of Birmingham, Birmingham I5, England)
}

\begin{abstract}
Three potholes and a narrow channel cut into bedrock in a side-hill position were observed beneath an Irish Sea till west of Wolverhampton, England. The potholes and the channel are believed to have been cut by subglacial or latero-glacial streams flowing beneath or immediately beside the Irish Sea ice sheet. They were later choked by sand and gravel from this ice sheet and capped by till which ended the glaciofluvial deposition. Deposits below and above the till have been ${ }^{14} \mathrm{C}$ dated at 30655 and ${ }^{1} 3490$ years B.P. at localities between 13 and $27 \mathrm{~km}$ north of the trench section described.
\end{abstract}

RÉsumé. Moulins de glacier de l'époque tardive Weichselienne près de Wolverhampton, Angleterre. Trois moulins de glacier et un chenal étroit creusé dans le socle rocheux sur le côté d'une colline ont été observés sous la couverture morainique de la mer d'Irlande à l'ouest de Wolverhampton, Angleterre. Les moulins et le chenal sont supposés avoir été creusés par des fleuves sous-glaciaires ou latéraux s'écoulant sous ou immédiatement près des dépôts glaciofluviaux de la glace de la mer d'Irlande. Plus tard ils ont été frappés par du sable et du gravier de cette nappe de glace et surmontés par des dépôts glaciaires qui finissaient les dépôts fluvioglaciaires. Les dépôts dessous et dessus ces débris glaciaires ont été datés par ${ }^{14} \mathrm{C}$ à 30655 et ${ }^{1} 3490$ années en des sites entre 13 et $27 \mathrm{~km}$ au nord de la section décrite.

Zusammenfassung. Gletschertöpfe aus der späten Weichselvereisung nahe Wolverhampton, England. Drei Gletschertöpfe und ein enger Kanal, eingeschnitten in den Felsgrund an einer Hangseite, wurden unter einer diluvialen Ablagerung an der Irischen See westlich von Wolverhampton, England, gefunden. Es wird vermutet, dass die Gletschertöpfe und der Kanal durch subglaziale oder randliche Schmelzwasserströme des Eislobus der Irischen See eingeschnitten wurden. Sie wurden später von Sand und Schutt aus diesem Eislobus zugefüllt und durch eine Schotterbank überdeckt, womit die glaziofluviatile Ablagerung beendet wurde. Ablagerungen unter und über der Bank an Orten, die zwischen 13 und $27 \mathrm{~km}$ nördlich der beschriebenen Grabenzone liegen, wurden mit ${ }^{14} \mathrm{C}$ auf 30655 bis $1349^{\circ}$ Jahre vor der Gegenwart datiert.

\section{INTRODUCTION}

In 1969 Pleistocene deposits north and west of Wolverhampton were well exposed in a number of gas pipe-line trenches. In a particularly deep section between two roads west of Lower Penn, near Wolverhampton (Fig. I) (lat. $52^{\circ} 34^{\prime} \mathrm{o} 33^{\prime \prime}$ N., long. $2^{\circ}$ I $3^{\prime} \mathrm{o} 4^{\prime \prime}$ W.; National Grid Reference SO/89 8523.9669), late Weichselian till rests on pockets of sand and gravel infilling potholes in Upper Mottled Sandstone (Triassic). In $6 \mathrm{I} \mathrm{m}$ of trench there were three potholes and a narrow channel all exhibiting signs of former fluvial erosion which either predated or was contemporaneous with the ice advance that deposited the overlying till. The nature of the gravels infilling the potholes indicated that they had been cut and infilled in association with an Irish Sea ice advance, and not cut as normal river potholes during an earlier interstadial or interglacial episode. As far as the author is aware, the glaciofluvial potholes described here are the most southerly recorded in Britain and also one of the rare cases where they are associated with a dated ice advance.

Potholes originating by glaciofluvial action are well known in formerly glaciated areas in parts of Europe and North America but they are rare in the British Isles. Examples have been found at Ballylusk, County Wicklow, Ireland (Egan and Kilroe, I897, p. I 55); near Loch na Keal, Mull, Scotland (Richey, I913, p. 53) and on Meall Cumhann, Glen Nevis, Scotland (Bailey and Maufe, I916, p. 223). In England the only previously recorded examples are at Birkenhead (Lomas, I893, p. 66) and the Kailpot, beside Ullswater in the English Lake District (Marr, I926).

The earliest hypothesis used to explain the glaciofluvial potholes was that water, pouring down moulins in the ice, struck the bedrock or boulders resting on the bedrock, and created a pothole at that point. This has been more fully explained by Brögger and Reusch (1874), and Upham (I900). Other authors, principally Gilbert (I906), Fuller (1925), Marr (1926) and Fægri (1952), have used the moulin hypothesis to explain potholes in formerly glaciated areas. 
A number of objections to the moulin hypothesis have been raised and it is claimed that not only will intervening ice prevent water from falling directly to the glacier bed but ice movement will tend to seal the moulin before the pothole has had time to develop. The objections have been more fully explained by Alexander (I932, p. 310-I2) and Higgins (I957, p. I2).

The currently accepted hypothesis is that potholes are formed by rapidly flowing subglacial or latero-glacial streams, with water entering the pothole obliquely at a low angle and then spiralling upward from the centre (Alexander, I932; Ängeby, 1951 ; Streiff-Becker, I95I[a], [b]). Summaries of the literature are to be found in Charlesworth (1957, p. 230-40) and Embleton and King (1968, p. I48-50).

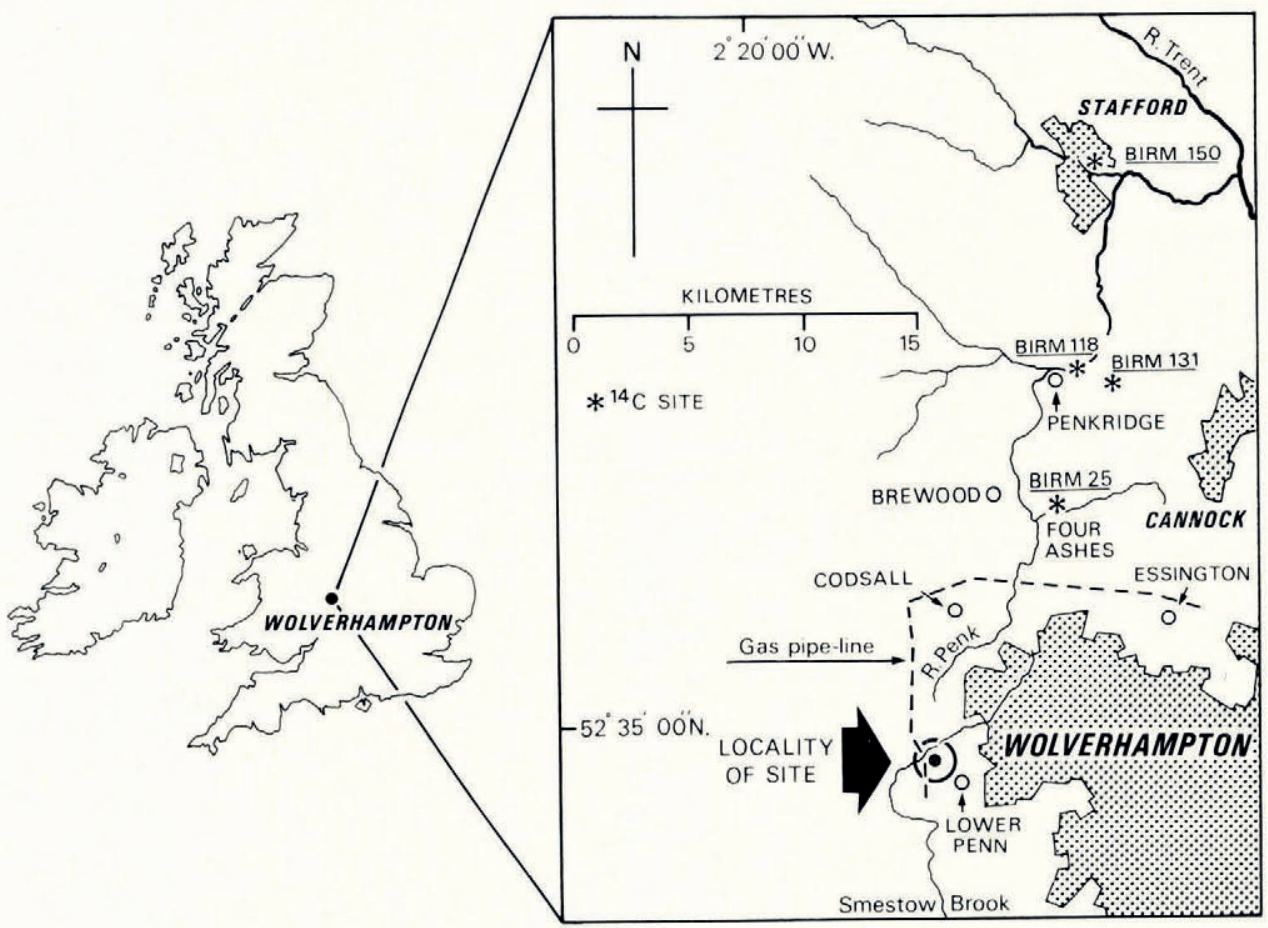

Fig. 1. Location of sites referred to in the text.

\section{General Field RELATionships}

The trench section in which the potholes were exposed lies on the northern flank of a small hill sloping towards the Smestow Brook (Fig. I). The hill is largely bedrock controlled but it is modified by a deposit of red-brown Irish Sea till with Scottish, Lake District, Irish Sea and other erratics, some of which are striated. The till sheet has been traced by means of gas and sewerage pipe-lines, bore-hole records and auger traverses over a wide area west and north of Wolverhampton, and is correlated (Morgan, unpublished) with the till of Four Ashes, north of Wolverhampton, which has been shown to be younger than 30655 years B.P. (Birm. 25) (Shotton, I967). Several kilometres north of this locality (Fig. I) three ${ }^{{ }^{4}} \mathrm{C}_{\text {dates of }}{ }^{\mathrm{I}} 349^{\circ}$ (Birm. I 50), i I 660 (Birm. I3 I) and I I 580 years B.P. (Birm. i I8) on deposits post-dating the till give minimum ages for ice retreat.

In the trench section described here the till has a maximum thickness of $5.6 \mathrm{~m}$ (Fig. 2), but it probably becomes thicker to the north were the bedrock contact falls steeply. 


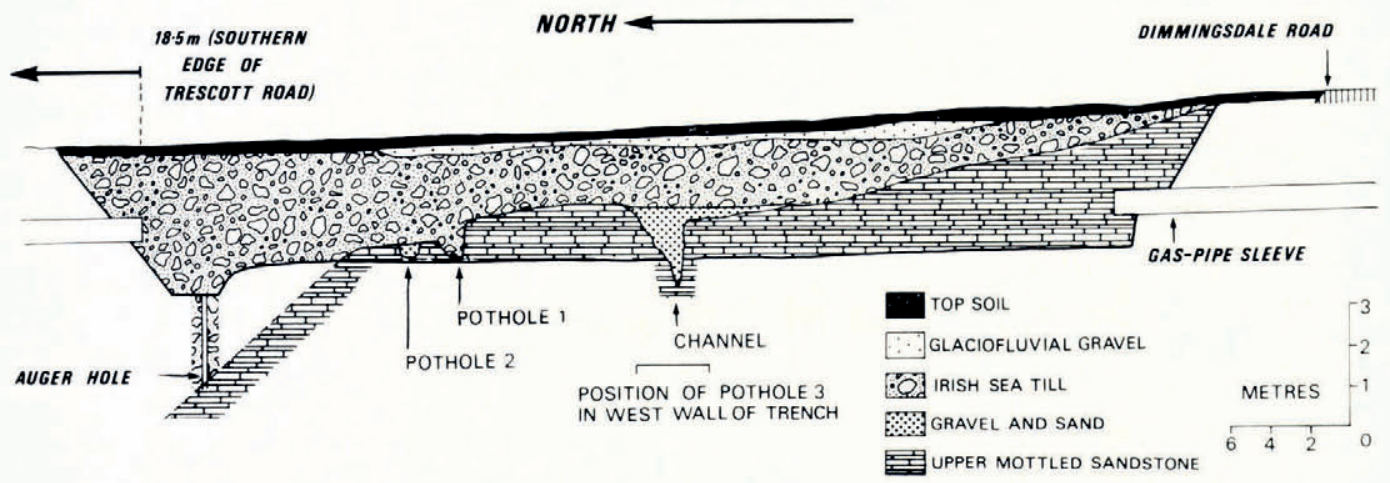

Fig. 2. Section of trench in which the potholes and channel were revealed.

\section{DESCRIPTION OF THE STRUCTURES}

Pothole $I$ is intermediate in size between potholes 2 and 3 . Immediately below the southern edge of the pothole there was a crack $6 \mathrm{~cm}$ wide and $25 \mathrm{~cm}$ deep extending down from the floor. The crack was traced laterally for $42 \mathrm{~cm}$ before it was cut out by the trench excavation. It was infilled with coarse sand, gravel and small cobbles, and also contained minute fragments of marine shells. Intimately associated with the top few centimetres of the crack was a fine brown sand (not exceeding $2.5 \mathrm{~cm}$ in thickness) extending across the base of the pothole. Above the fine sand the pothole was infilled with till (Figs. 2 and 3 ) containing small fragments of marine shells.

The morphology of pothole 2 is shown in Figures 4, 5 and 6. This was the only one completely excavated and it had a maximum depth of $84 \mathrm{~cm}$. The most pronounced bedrock structures inside the pothole were helical flutings on the margins, a rounded residual central hump, basal undercut grooves and small hollows beneath the general floor (Figs. 5 and 6 ). The
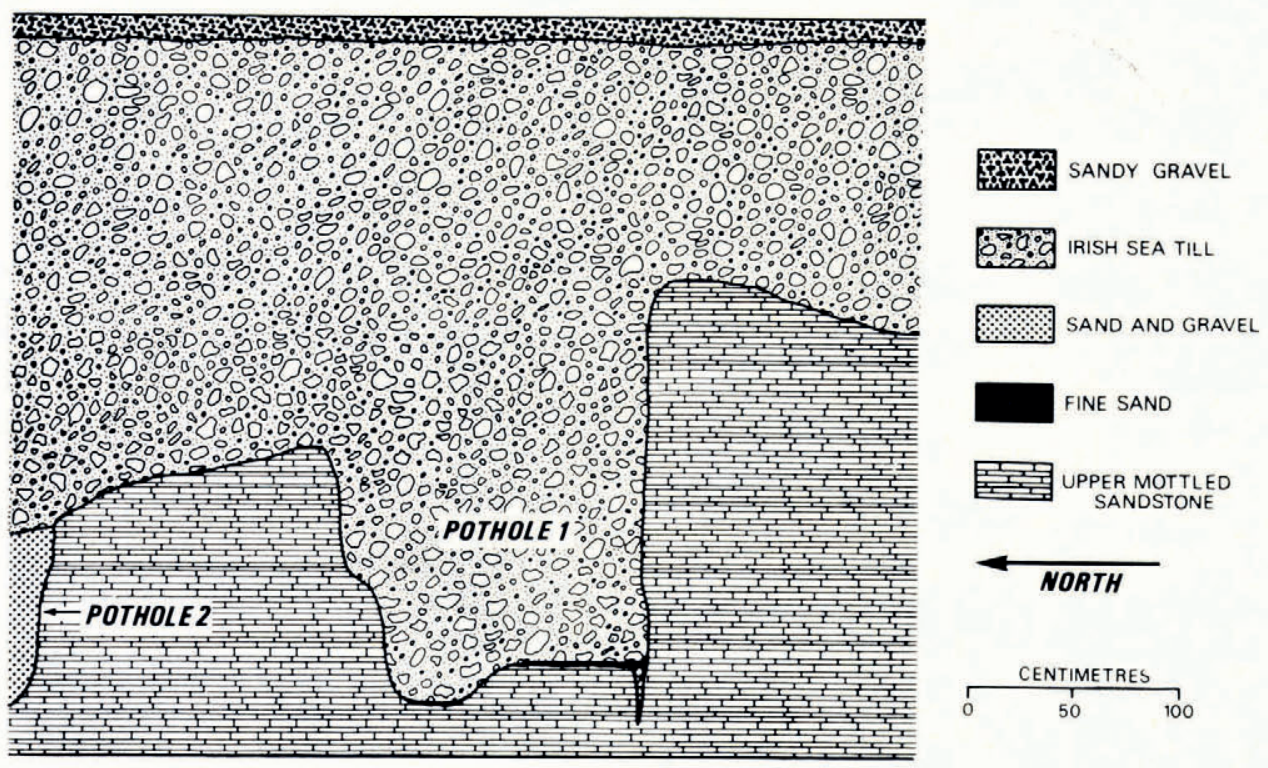

Fig. 3. Section through pothole I. 


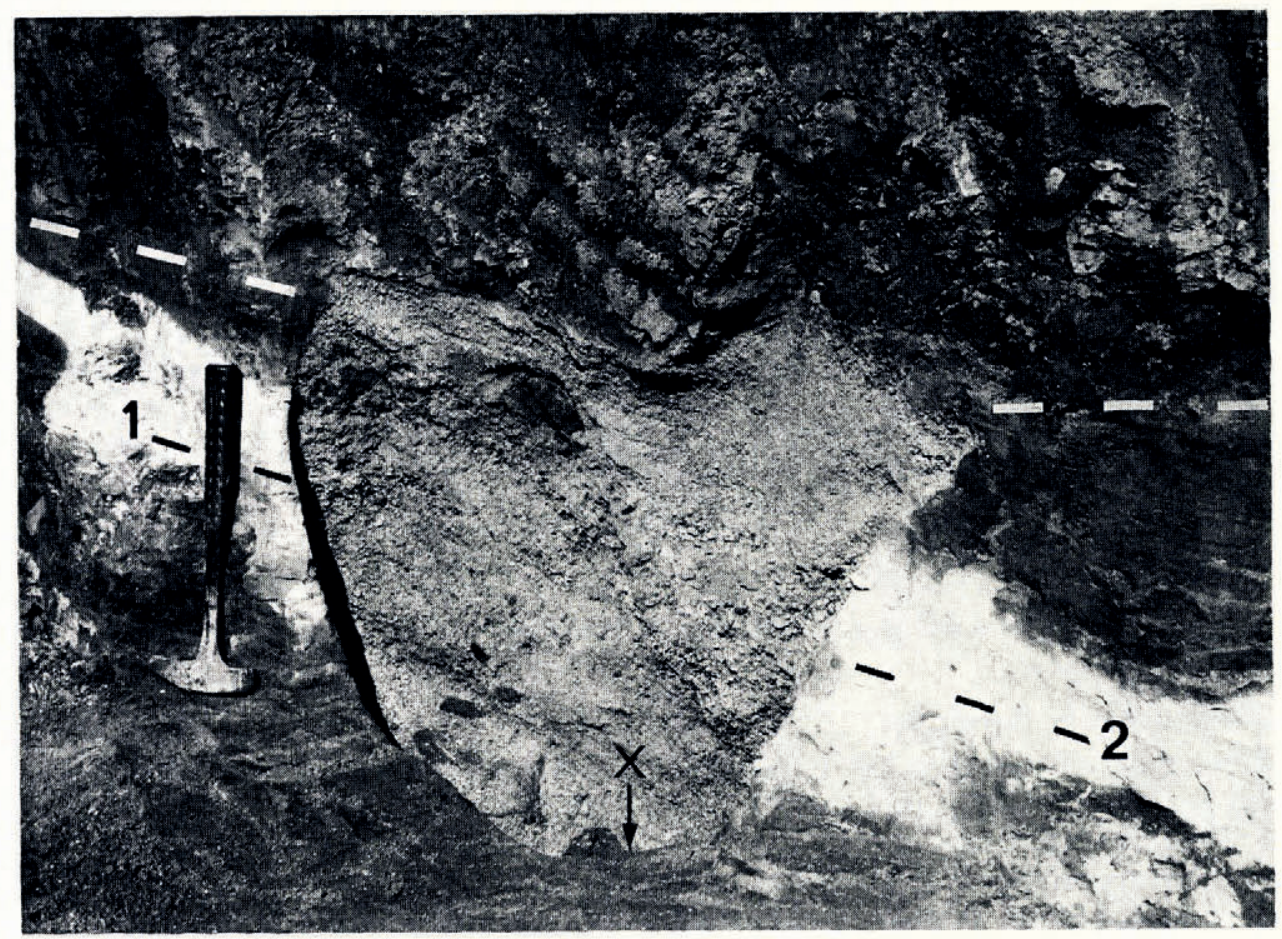

Fig. 4. Pothole 2 before excavation. The bedrock/till contact is indicated by a dashed white line and the cast wall of the trench with a dashed black line $I-2$. Darker fragments of bedrock can be seen among the inflling gravels. The position of $X$ is marked for comparison with Figures 5 and 6 . The hammer shaft is $33 \mathrm{~cm}$ long.

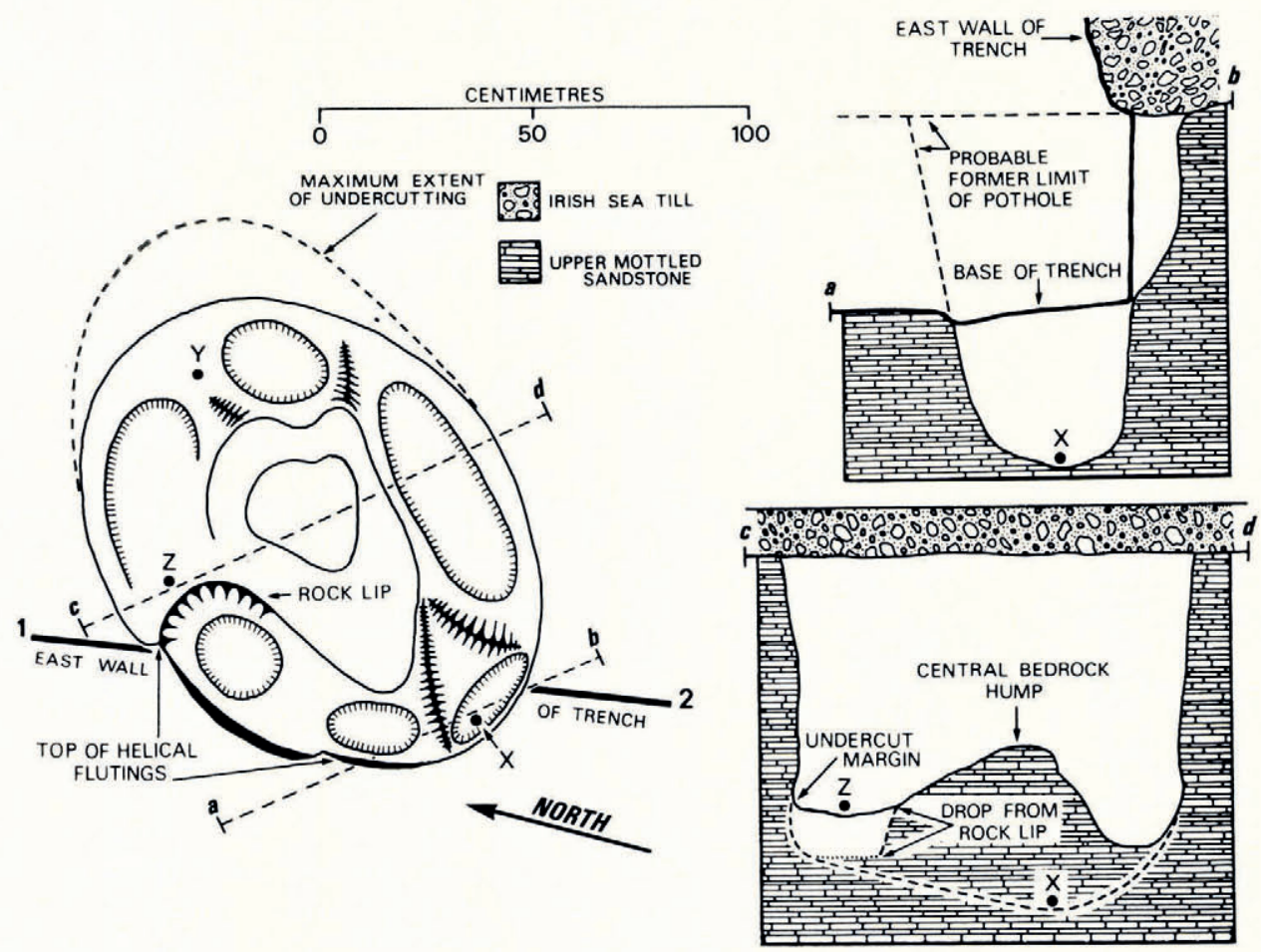

Fig. 5. Plan and two sections of pothole 2 to illustrate its form and dimensions. From $X($ depth $84 \mathrm{~cm})$ the floor slopes upwards to $Y$ (depth $53 \mathrm{~cm})$. From $Y$ there is a gradual slope down to $Z$ (depth $61 \mathrm{~cm})$ below which is a well-defined rock lip. 
helical flutings narrow downwards in an anti-clockwise direction from $46 \mathrm{~cm}$ (crest to crest) at the top of the pothole to $3 \mathrm{I} \mathrm{cm}$ at the bottom. The central hump is elongated parallel to the long axis of the pothole, being raised 8 and $28 \mathrm{~cm}$ above the floor on the north-eastern and south-western sides, respectively. Where they are not fluted, the sides are vertical or slightly overhanging and the northern and eastern quadrants are undercut to a depth of $18 \mathrm{~cm}$.

The infilling material (Fig. 4) consisted of crudely stratified fine and coarse sand, gravel and cobbles. The rock fragments were largely locally derived but Scottish white granite, Eskdale granite, spotted slate, Carboniferous limestone and Cretaceous flints were recovered,

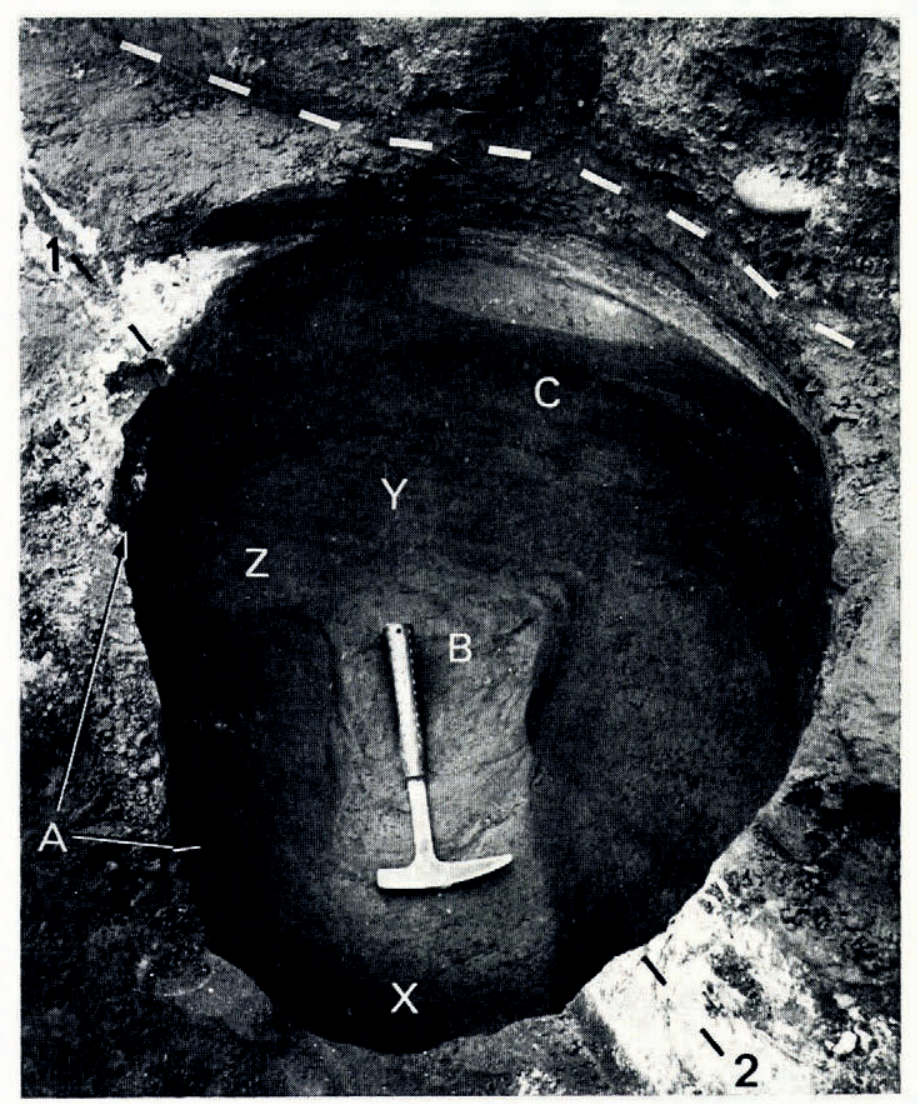

Fig. 6. Pothole 2 after excavation. The original line of the face is marked by a dashed black line $I-2$, and the bedrock/till contact by a dashed white line. The features in this photograph are: $A$. The crests of the helical flutings; $B$. The rounded central hump; $C$. The basal undercut grooves. $X, Y$ and $Z$ as in Figure 5.

together with Jurassic fossils and about $25 \mathrm{~g}$ of Pleistocene marine shells. The largest cobbles in the deposit were slabs of local bedrock with rounded edges which appeared to be randomly scattered throughout the infill, and reached dimensions of $33 \times 23 \times 6 \mathrm{~cm}$. Ioo $\mathrm{kg}$ of pebbles and cobbles in excess of $2.5 \mathrm{~cm}$ were removed from the pothole and one andesitic erratic $(12 \times 8 \times 4 \mathrm{~cm})$ from the base of the eastern side was striated.

Pothole 3 was by far the largest revealed in the trench and it comes into the category of a true "giant kettle". The exposed width was $3.4 \mathrm{~m}$ and the maximum depth was $2.2 \mathrm{~m}$, these being minimum figures. Horizontal auger holes at the top of the pothole, $6 \mathrm{r} \mathrm{cm}$ below the till 
junction, with a maximum penetration of $3.25 \mathrm{~m}$ (Fig. 7) failed to contact bedrock giving another minimum diameter. The bedrock walls on both sides of the pothole plunge steeply towards a smooth base which is overdeepened into a number of minor shallow depressions.

This pothole is completely filled with an ascending sequence of cobbles, gravels (with marine shells) and sands, and it is completely sealed with till. The most interesting feature was a large granite erratic $\left(76 \times 67 \times 5^{8} \mathrm{~cm}\right)$, weighing at least $800 \mathrm{~kg}$, separated from the bedrock
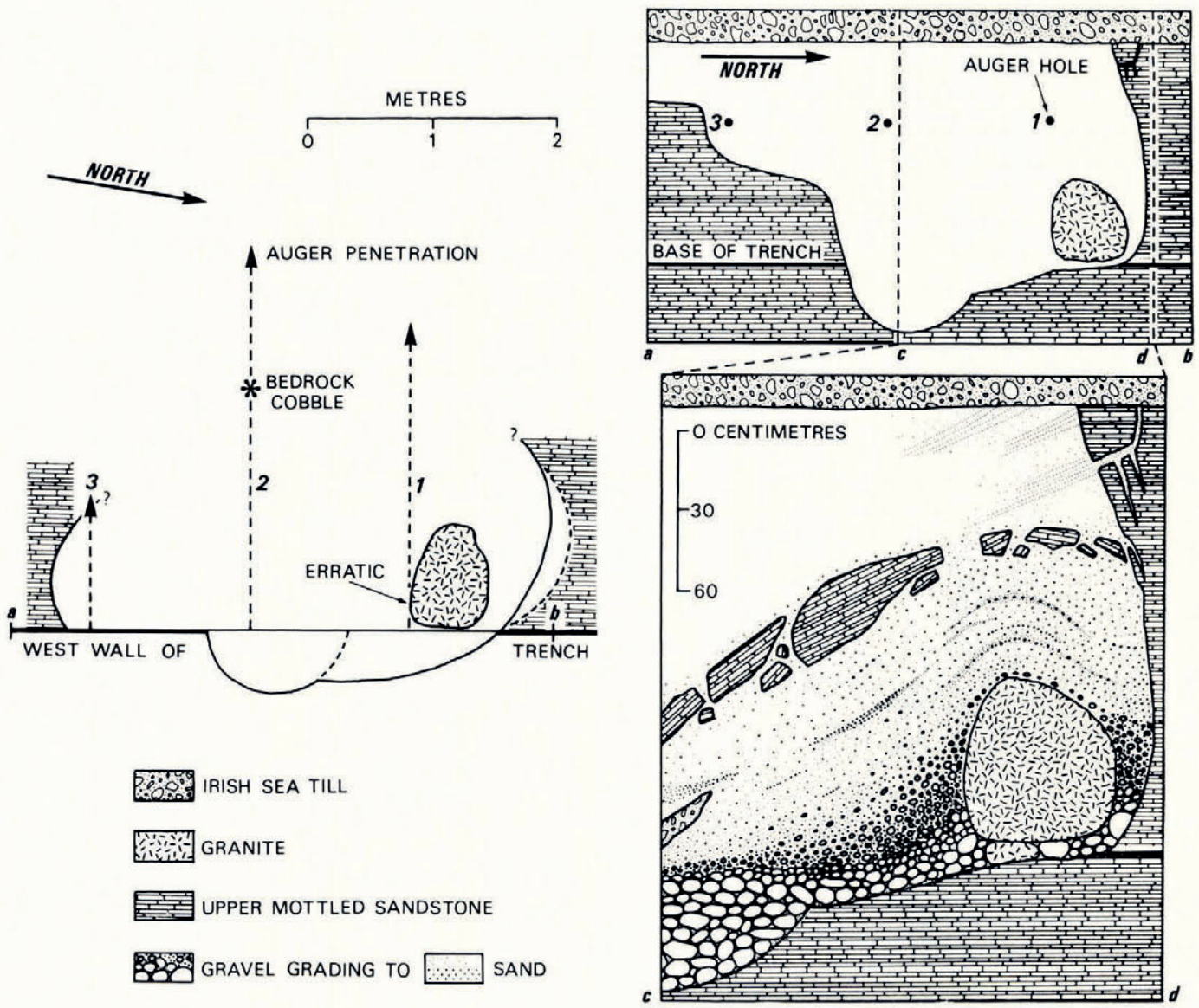

Fig. 7. Plan and two sections of pothole 3 , giving its dimensions. Note the sand-filled cracks in the bedrock wall, the sandstone spalling from the face, the sheet of till in the gravels, and the gravel and sand draped over the large erratic.

wall by approximately $18 \mathrm{~cm}$ of cobbles and gravels and from the floor by several smaller erratics, the largest of which (an Eskdale granite) was $1_{5} \times 12 \times 9 \mathrm{~cm}$. The average size of the largest cobbles in the base of pothole 3 was $10 \times 8 \times 5 \mathrm{~cm}$. The graded nature of the infill is diagrammatically shown in Figure 7 with the coarser material in the north-east corner "draped" over the large erratic. During the excavation of the gravels and sands around the erratic a discontinuous line of sandstone blocks was found. These were traced back through the infill until the bedrock wall was encountered, and certain of the blocks were seen to be spalls from the side of the pothole. The sandstone surrounding the pothole was crossed by several vertical 
cracks parallel to the bedrock wall. These cracks were infilled with medium to coarse sands. Also found in association with the coarser infill, but below the sandstone blocks, was a sheet of till approximately $65 \mathrm{~cm}$ long, $8 \mathrm{~cm}$ thick and in excess of $35 \mathrm{~cm}$ wide interbedded with the gravels. Above the gravels the infilling deposits graded into a medium to fine sand which gave a banded appearance with each of the bands being about $5 \mathrm{~mm}$ wide.

A steep-sided north-east-trending bedrock channel (Fig. 8) was observed on the east side and floor of the trench, and it was traced to within $80 \mathrm{~cm}$ of pothole 3 . The bedrock surface was

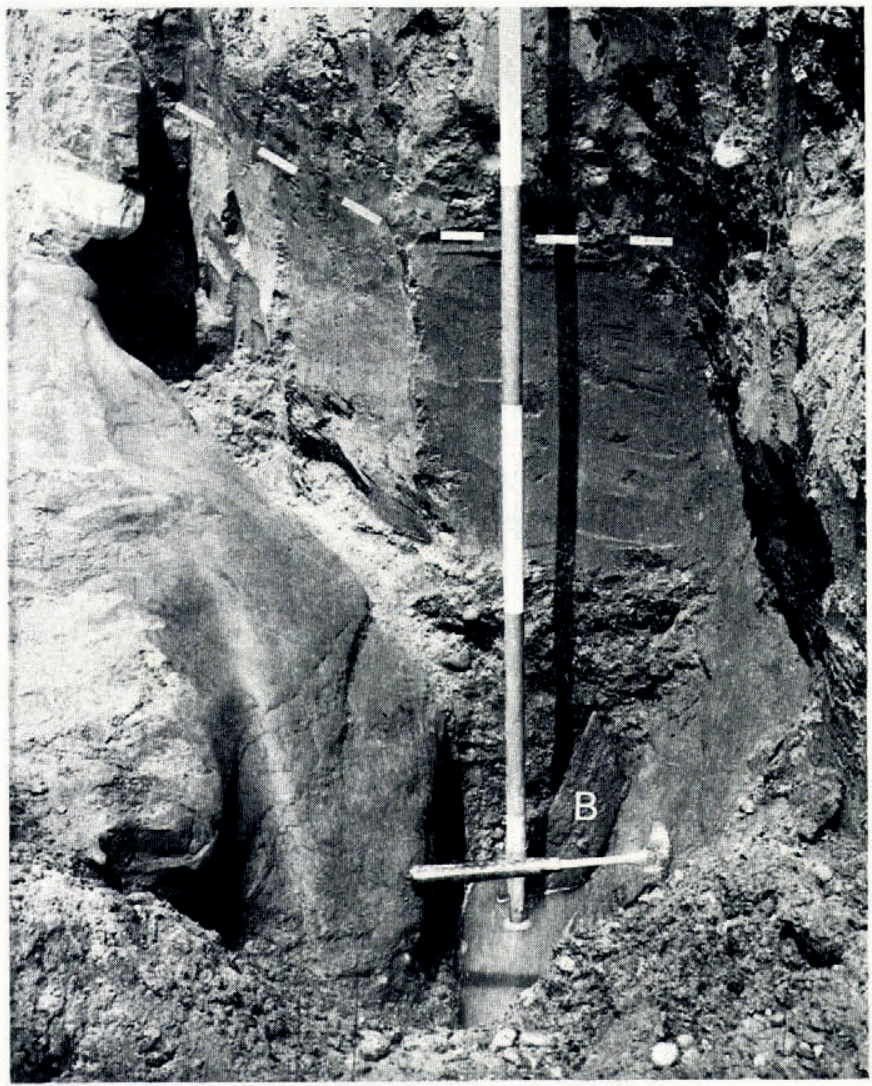

Fig. 8. The bedrock channel in the east wall of the trench after partial excavation. The water-worked sandstone bedrock and graded infill can be seen in the centre. The angular block of basalt $(B)$ was found beneath the water with its long axis parallel to the axis of the channel. The infill/till contact is marked by a dashed white line. The scale in the centre is in feet $(30 \mathrm{~cm})$.

fluted and showed typical signs of fluvial erosion. The deposits infilling the channel consisted of coarse bedrock fragments and pebbles at the base (the largest being an angular basalt block measuring $33 \times$ I I $\times 9 \mathrm{~cm}$ ), grading upwards through coarse gravels to medium and fine sands, a sequence identical to that encountered in pothole 3 . The infilling gravels and sand were excavated back from the face along the axis of the channel for $1.5 \mathrm{~m}$ and the same stratigraphic sequence was observed over this distance. The coarse sand fraction contained fragments of marine shells and the fine sand was capped by till as in the nearby potholes. 


\section{Discussion}

After pothole I had been eroded it was partially infilled with gravels and sands, the erratic content of which reveals an association with an Irish Sea ice sheet. Probably the pothole was never completely infilled with gravel and sand, and possibly the crack in the side and base acted as an avenue of escape to water carrying the gravel and sand debris. At some later date the pothole was completely infilled with Irish Sea till.

Pothole 2 appeared to have been cut by water spiralling downwards, rotating in an anticlockwise direction, and flowing out over the central hump in the manner suggested by Alexander (1932, p. 319). The state of preservation of the sea shells in the gravels shows that they had not been transported far by fluvial action, and suggests the presence of an Irish Sea ice sheet nearby. The till capping finally closed the depositional sequence inside the pothole.

Pothole 3 and the bedrock channel are discussed together since it is believed that both are part of the same erosional structure, the channel being the exit from the pothole. This is suggested by the lateral extent of the channel (traced practically to the side of the pothole) and the similarity of the infilling debris, particularly the graded sequence of deposition. The location of the large granite erratic near the base suggests that it was emplaced when the pothole was empty or nearly empty. Whether or not the granite was involved in the rotational erosion is difficult to say. In view of the perched position of this erratic on the side, it seems likely that it arrived after the pothole had been half excavated, and remained in position whilst the excavation of the lower section continued. It must, however, have been emplaced before the accumulation of the graded debris as this material is draped over the top of the erratic. The erratic's size apparently indicates that the transporting ice was not too far away and this is substantiated by the later deposition of the sheet of till (in the gravels) which may well have been transported as a frozen block or perhaps even dropped into position. The closing phases of the depositional sequence indicate a gradual choking of the pothole with diminishing water supply, evidenced by the graded infill, and the pothole was finally sealed by the deposition of the overlying Irish Sea till.

\section{Conclusions}

It has been shown that the three potholes and the fluvially eroded channel cut into the bedrock in a side-hill position can be related to the last advance of the Irish Sea ice. The presence of a large granite erratic weighing at least $800 \mathrm{~kg}$, together with a sheet of till in one pothole, and associated marine shells and erratics in all of the potholes suggests that the ice sheet from which they were derived was very close by and quite possibly overhead. The potholes are believed to have been cut by subglacial or immediate latero-glacial streams, then choked with gravel and sand from an Irish Sea ice sheet, and finally sealed with an Irish Sea till. Field mapping has shown that this till is the same as that in the area between Four Ashes and Stafford where lower and upper age limits are respectively 30665 and I 3490 years в.P.

\section{Acknowledgements}

I wish to express my appreciation to the West Midlands Gas Board and Mitchell-Socea for allowing me to examine their pipe-line excavations, and particularly for their help and consideration in the excavation and recording of the trench section described here. I am also grateful to Professor F. W. Shotton, Dr F. Moseley and Dr R. J. Adie for their helpful suggestions during the final preparation of the manuscript.

\section{MS. received ${ }_{15}$ September 1969}




\section{REFERENCES}

Alexander, H. S. 1932. Pothole erosion. Journal of Geology, Vol. 40, No. 4, p. 305-37.

Ängeby, O. 1951. Pothole erosion in recent water-falls. Lund Studies in Geography, Ser. A, No. 2, p. I-34. [English summary of a longer paper entitled "Evorsionen i recenta vattenfall". Kungl. Fysiografiska Sällskapets $i$ Lund Handlingar, N.F., Bd. 61, Nr. I0, 1951, p. I-89.]

Bailey, E. B., and Maufe, H. B. r916. The geology of Ben Nevis and Glen Coe, and the surrounding country. London, H.M.S.O. (Memoirs of the Geological Survey. Scotland. Explanation of sheet 53.)

Brögger, W. C., and Reusch, H. H. 1874. Giants' kettles at Christiania. Quarterly fournal of the Geological Society of London, Vol. 30, No. 120, p. 750-71.

Charlesworth, J. K. 1957. The Quaternary era, with special reference to its glaciation. London, Edward Arnold. 2 vols.

Egan, F. W., and Kilroe, J. R. 1897. Pleistocene and glacial. Summary of Progress of the Geological Survey of the United Kingdom for 1897 , p. 115 .

Embleton, C., and King, C. A. M. 1968. Glacial and periglacial geomorphology. [London], Edward Arnold.

Fægri, K. 1952. On the origin of pot-holes. Fournal of Glaciology, Vol. 2, No. I I, p. $24-25$.

Fuller, M. B. 1925. The bearing of some remarkable potholes on the early Pleistocene glaciation of the Front Range, Colorado. Journal of Geology, Vol. 33, No. 3, p. 224-35.

Gilbert, G. K. Igo6. Moulin work under glaciers. Bulletin of the Geological Society of America, Vol. 17, No. 3, p. $317-20$.

Higgins, C. G. 1957. Origin of potholes in glaciated regions. Fournal of Glaciology, Vol. 3, No. 2 1, p. 11 1-12.

Lomas, J. i 893. On a glacier mill at Arno quarry, Birkenhead. Glacialists' Magazine, Vol. 1, No. 2, p. 66-67.

Marr, J. E. 1926. The Kailpot, Ullswater. Geological Magazine, Vol. 63, No. 8, p. 338-41.

Morgan, A. V. Unpublished. The glacial geology of the area north and west of Wolverhampton, Staffordshire. [Ph.D. thesis, Dept. of Geology, University of Birmingham, Birmingham, England, I97o.]

Richey, J. E. 1913. Pleistocene and Recent. Summary of Progress of the Geological Survey of Great Britain for 1913, p. $52-53$.

Shotton, F. W. 1967. Age of the Irish Sea glaciation of the Midlands. Nature, Vol. 21 5, No. 5108, p. 1366.

Streiff-Becker, R. I95 [a]. Pot-holes and glacier mills. Fournal of Glaciology, Vol. I, No. 9, p. 488-90.

Streiff-Becker, R. I95 [ [b]. Pot-holes and glacier mills. Journal of Glaciology, Vol. i, No. Io, p. 582. [Letter.]

Upham, W. I90o. Giants' kettles eroded by moulin torrents. Bulletin of the Geological Society of America, Vol. 12 , No. I, p. 25-44. 